\title{
KONSEP BEKERJA SEBAGAI AD MAJOREM DEI GLORIAM: SEBUAH UPAYA PEMENUHAN SACRED CALLING
}

\author{
Bimo Setyo Utomo
}

\begin{abstract}
Work is an inseparable part of human existence in this world. Nevertheless, there are different ways of understanding and addressing the concept of work. The contribution of thought that most influences Christian life about work is the existence of two patterns: secular work (working in the secular field) and contemplative work (working in the spiritual field). The two patterns has even begun since the Middle Ages and still feels its influence today. In this paper, the researcher seeks to trace the development of concepts about work and compare them with concepts in the Bible which will lead to the discovery of sacred calling as fulfillment of Ad Majorem Dei Gloriam in the concept of work.
\end{abstract}

Keywords: work, calling, secular work, spiritual work

\begin{abstract}
Abstrak
Bekerja adalah bagian yang tak terpisahkan dari eksistensi manusia di dunia ini. Meskipun demikian terdapat perbedaan cara memahami dan menyikapi mengenai konsep bekerja. Sumbangsih pemikiran yang paling mempengaruhi kehidupan kekristenan tentang bekerja adalah adanya pembagian dua kutub, yaitu: secular work (bekerja di bidang sekuler) dan contemplative work (bekerja di bidang rohani). Pembagian dua kutub tersebut bahkan sudah dimulai sejak Abad Pertengahan dan masih terasa pengaruhnya hingga masa kini. Dalam makalah ini, peneliti berusaha menelusuri perkembangan konsep mengenai bekerja dan membandingkannya dengan konsep dalam Alkitab yang akan bermuara dalam penemuan panggilan kudus (sacred calling) sebagai pemenuhan dari Ad Majorem Dei Gloriam di dalam konsep bekerja.
\end{abstract}

Kata kunci: kerja, panggilan, sekular, kerja sekuler, kerja rohani 


\section{PENDAHULUAN}

Kerja merupakan kodrat manusia yang tidak terpisahkan dari eksistensi manusia di dunia ini. Bahkan kira-kira sepertiga dari hidup manusia dihabiskan untuk melakukan pekerjaannya. Menolak bekerja sama saja dengan melawan kodratnya. Dampaknya bisa bermacammacam, dari hidup gelisah, rendah diri, sampai merasa hidup tidak memiliki nilai. Karena bekerja merupakan sesuatu yang sangat penting, maka tidak heran apabila John Stott menyatakan bahwa manusia memerlukan prinsip kerja sebagai dasar bagi sikapnya dalam bekerja. $^{1}$ Pada perkembangannya, meskipun kerja merupakan kodrat manusia, tetapi ada multipersepsi dan interprestasi di dalamnya.

Perkembangan dunia memiliki konsep yang berbeda-beda mengenai kerja. Mayarakat Yunani kuno misalnya, mereka memisahkan antara pekerja pemetik bulir gandum di ladang dengan pekerjaan orang bebas. Yang satu dianggap budak dan yang satu dianggap orang merdeka. Mereka menganggap tubuh yang bekerja sama saja dengan orang yang terbelenggu dan terpenjara karena dosa. Pemikiran seperti ini, pada masa selanjutnya akan membuat masyarakat Yunani menganggap rendah

${ }^{1}$ John Stott, Isu Isu Global Menentang Kepemimpinan Kristiani (Jakarta: Yayasan Komunikasi Bina Kasih OFM, 2005) 227. orang yang bekerja menggunakan tangan, dan menjunjung tinggi orang yang bekerja menggunakan pikiran (kaum filsuf dan orator).

Dalam kekristenan pun banyak sekali konsep yang berkembang mengenai kerja, dimulai dari Bapa Gereja Agustinus yang membagi kehidupan manusia menjadi dua, yaitu kehidupan aktif (de vita activa) yang meliputi kehidupan kerja di dunia sekuler, dan kehidupan kontemplatif (de vita contemplativa) yang meliputi pekerjaan di bidang agama atau rohani. ${ }^{2}$ Pandangan seperti ini terus merasuk sampai ke zaman sekarang ini. Tidak sedikit kelompok yang berpandangan bahwa bekerja dalam bidang rohani lebih mulia dibandingkan bekerja di dunia sekuler. Para tokoh Reformator seperti Luther dan Calvin pun memberikan pandangannya tentang kerja yang mempengaruhi masyarakat Barat pada saat itu untuk memproyeksikan perilaku religius mereka ke dalam aktivitas sehari-hari, termasuk dalam dunia kerja.

Melihat hal ini, jika kerja merupakan kodrat yang bisa membuahkan multipersepsi dan interprestasi, maka akan mucul pertanyaan mengenai bagaimana perspektif yang dianggap ideal bagi manusia, khususnya dalam memandang dan

\footnotetext{
${ }^{2}$ St. Augustine, The City of God (New York:
} The Modern Library, 1950) 247. 
menyikapi aktivitas kerja. Kompleksitas pemahaman kerja ini menarik untuk dikaji, khususnya dalam perkembangannya di dalam sejarah dan tentu saja dalam perspektif Alkitab. Melalui ini semua, akan coba ditarik suatu pemahaman tentang kerja secara biblikal, sehingga mampu memberi kerangka berpikir dan bertindak dalam aktivitas kerja sehari-hari.

Salah satu pernyataan yang menjelaskan kaitan antara religiusitas dan kerja adalah ungkapan yang diberikan oleh Santo Benediktus yang dikenal dengan istilah Ora et Labora (berdoa dan bekerja). Hal ini menunjukkan bahwa umat Allah dituntut untuk menyeimbangkan dan tidak memisahkan antara religiusitas dan pekerjaan. Dengan konsep yang benar tentang pekerjaan, maka orang Kristen harusnya dapat meletakkan pekerjaannya sebagai sarana mewujudkan Ad Majorem Dei Gloriam (untuk kemuliaan Allah yang lebih besar). Jika sudah demikian, dapat dipastikan bahwa etos kerja dan tanggung jawab dalam bekerja akan terbangun dengan positif, sebab orang yang tidak memiliki konsep yang benar tentang pekerjaan akan kehilangan semangat, sukacita, dan berujung kepada perspektif dan sikap negatif dalam bekerja. ${ }^{3}$
Tujuan penelitian dalam makalah ini yang pertama adalah untuk menunjukkan dan menjelaskan perkembangan wawasan dunia mengenai kerja dan juga referensi biblikal terhadap konsep kerja yang ada dalam Alkitab. Kedua, penelitian ini juga memberikan manfaat, baik secara teoretis dan praksis. Secara teoretis, penelitian ini akan memberikan kontribusi dan rekomendasi dalam teologi kerja (theology of work). Secara praksis, penelitian ini juga akan memberikan manfaat bagi para pekerja dalam memaknai pekerjaannya untuk memuliakan Tuhan.

\section{METODOLOGI}

Metodologi yang digunakan dalam penelitian ini adalah fenomenologi dengan pendekatan kualitatif secara literatur untuk mengumpulkan informasi, menjelaskan, dan menganalisis perkembangan makna kerja yang mempengaruhi pemikiran pada zaman Abad Pertengahan dan masa kini. Penelitian ini menggunakan kajian biblikal yang bersifat tematik untuk menjelaskan landasan Alkitab mengenai bekerja dan menganalisisnya sebagai pendukung terhadap konsep Ad Majorem Dei Gloriam. 


\section{ANALISIS DAN HASIL PENELITIAN}

Perkembangan dan Distorsi Makna Bekerja

Pada masa Yunani kuno, ada tiga konsep yang berkembang tentang bekerja yang menghiasi kehidupan penduduk kota Athena pada waktu itu, yaitu:

Pertama, kerja adalah kehidupan yang paling hina bagi manusia, sebab bekerja merupakan penindasan hidup bagi manusia Yunani kuno. Hal ini disebabkan pemikiran klasik dalam masyarakat Yunani pada saat itu bahwa bekerja bagi seorang yang merdeka merupakan sebuah kehinaan. Itu sebabnya yang bekerja adalah para budak yang didapat lewat tawanan perang maupun melalui pembelian. ${ }^{4}$ Bahkan pada masa itu Aristoteles pernah mengatakan bahwa hanya warga negara yang memiliki waktu terluang saja yang boleh bersuara tentang pemerintahan, karena negara yang baik adalah negara yang tidak memberikan kedudukan kepada warga negara yang bekerja kasar. $^{5}$

Kedua, kerja yang mengandalkan pikiran lebih mulia dibandingkan kerja yang mengandalkan tangan. Pada masa Yunani kuno ada semacam pandangan populer yakni memenangkan perdebatan dengan keahlian mengolah kata dan berpidato merupakan sebuah kehormatan. Oleh sebab itu, para cendekiawan bahasa, filsafat, dan pidato

${ }^{4}$ Mohammad Hatta, Alam Pikiran Yunani (Jakarta: Universitas Indonesia, 2006) 60-61. muncul dengan subur di seluruh negeri. Mereka pandai bersilat kata dan menukar ilmu pengetahuan untuk mendapatkan uang dan popularitas. Karena tujuan mereka adalah menjual pengetahuan, maka mereka tidak mempersoalkan kepada siapa pengetahuan itu dijual dan ilmu yang mereka ajarkan pun adalah pengetahuan yang lebih mementingkan kemenangan perdebatan dan keahlian kata tanpa pernah mempersoalkan kebenarannya. Oleh karena kepopularitasan mereka, maka terbentuk konsep bahwa pekerjaan yang tidak berhubungan dengan mengolah pikiran dan kata dianggap sebagai pekerjaan yang hina.

Ketiga, pembagian struktur kelas bagi pekerja. Plato berpendapat bahwa kebahagiaan bagi jiwa adalah saat terjadi harmoni antara nous (akal), thumos (keberanian), dan epithumia (nafsu). Itu sebabnya Plato membagi struktur kelas para anggota negara menjadi: penguasa (akal), prajurit (keberanian), dan produsen atau pekerja (nafsu), sehingga masing-masing warga negara dapat bekerja sesuai kemampuannya masing-masing. Pembagian struktur kelas seperti ini terjadi dari konsep dualisme Plato, yakni form and matter yang ia sintesa dari pemikiran Heraklitos dan Parminedes yang telah mempengaruhi seluruh epistemologinya.

${ }^{5}$ Louise Ropes Loomis, On Man In The Universe (New York: Walter J. Black, 1943) 104. 
Pada perkembangan selanjutnya, konsep dualisme Plato juga mempengaruhi pemikiran Bapa gereja mula-mula, seperti Eusibius yang hidup sekitar $315 \mathrm{M}$ misalnya. Ia menyatakan bahwa pekerjaan yang ada di dalam dunia ini dapat disebut bernilai tinggi jika memiliki keterkaitan dengan dunia spiritual dan sama sekali tidak berkaitan dengan dunia materi. Bahkan ia mengatakan menjadi pastor, imam, biarawan, biarawati merupakan jenis pekerjaan yang bernilai agung, dan ia menolak jenis pekerjaan biasa di dunia karena dinilai lebih rendah. ${ }^{6}$ Eusibius menekankan bahwa kepentingan rohani harus didahulukan dibandingkan kepentingan dunia, termasuk dalam urusan pekerjaan.

Demikian pula dengan Agustinus, bapa gereja yang melayani antara tahun 354$430 \mathrm{M}$ mengungkapkan pandangan dasarnya mengena konsep dunia, termasuk dunia kerja. Ia menyatakan bahwa kehidupan manusia pada dasarnya dibagi menjadi dua, yaitu kehidupan aktif (de vita activa) dan kehidupan kontemplatif (de vita contemplativa). ${ }^{7}$ Kehidupan aktif meliputi kehidupan kerja di dunia sekular, seperti pedagang, petani, buruh, tukang kayu, sedangkan kehidupan kontemplatif meliputi kehidupan kerja di bidang spiritual, seperti

${ }^{6}$ Lee Hardy, The Fabric of this World: Inquiries Into Calling, Career Choice, and the Design menjadi pastor, imam, biarawan, dan biarawati. Konsep Agustinus mengenai kehidupan aktif (de vita activa) dan kehidupan kontemplatif (de vita contemplativa) didapatkannya melalui perenungannya terhadap kisah Maria dan Marta (Luk. 10:38-40), dimana Maria memilih bagian yang terbaik dibandingkan Marta. Meskipun demikian, Agustinus tidak seperti Eusibius yang terlalu frontal merendahkan pekerjaan kehidupan aktif (de vita activa). Agustinus tetap memuji profesi pedagang, petani, buruh, tukang kayu yang ia anggap sebagai pekerjaan baik, namun bernilai hanya di dunia fana.

Pandangan Agustinus tersebut makin meluas dan bahkan mempengaruhi secara luas pemikiran di Abad Pertengahan. Pada masa ini secara tajam muncul dua kutub, yaitu: secular work (bekerja di bidang sekuler) dan contemplative work (bekerja di bidang rohani). Pada masa ini banyak orang yang tertarik menjadi rahib, biarawan, biarawati, dan pastor dengan membaktikan hidup mereka dengan cara asketis (menutup diri terhadap akses duniawi). Pada masa segala sesuatu yang bersifat rohani mendapatkan karpet merah dan dianggap lebih superior dibandingan dengan segala sesuatu yang bersifat duniawi. Bahkan

of Human Work (Grand Rapids: Eerdmans Publishing, 1990) 7.

${ }^{7}$ St. Augustine, 247 
Thomas Aquinas (1225-1274), seorang pemikir handal di masa ini terpengaruh oleh gagasan Agustinus tentang dunia kerja. Aquinas secara jelas membagi dua wilayah kehidupan kerja manusia, yakni kehidupan aktif (de vita activa) dan kehidupan kontemplatif (de vita contemplativa). Sama seperti Agustinus, ia menyatakan bahwa de vita contemplativa lebih mulia dibandingkan de vita activa. ${ }^{8}$

\section{Perspektif Alkitab Mengenai Kerja}

Allah Sang Pekerja Agung

Adalah suatu fakta dalam Alkitab bahwa tindakan kerja pertama kali dikenakan pada entitas Allah, dan bukan pada diri manusia. "Pada mulanya Allah menciptakan langit dan bumi” (Kej. 1:1), demikianlah Perjanjian Lama memberi kesaksian bahwa Allah adalah Sang Pekerja sejak semula. Ia giat bekerja selama enam hari penciptaan. Ia berfirman, berkreasi, melengkapi, serta memperindah karya-Nya dengan hasil yang Ia anggap baik (Kej. 1:10,12,18,21,25). Semuanya menyenangkan hati-Nya pada akhirnya (Kej. 1:31). Robert J. Banks memberikan beberapa penggambaran tentang perbandingan alkitabiah yang disarikan dari pekerjaan manusia untuk menggambarkan pekerjaan Allah,

${ }^{8}$ Simon M.Steer, Why Work? Careers and Employment in Biblical Perspective (Grand Rapids: Baker Book House, 1986) 19. diantaranya adalah: Allah sebagai komposer dan performer, pemahat, tukang kebun, pemahat, penjahit dan penghias, penjunan, tukang kebun, petani dan pembuat anggur, gembala dan pengkhotbah, tukang bangunan, arsitek, dan banyak lagi. ${ }^{9}$

Allah Sang Pekerja Agung itu juga telah menciptakan manusia segambar dengan Dia (Kej. 1:26-27), maka jika Allah bekerja, manusia juga harus bekerja pula. Allah membentuk bumi untuk didiami manusia. Berbeda dari hewan, manusia tidak bisa menjadikan bumi begitu saja sebagai tempat huninya. Tanah tidak langsung mendatangkan hal-hal baik untuk dinikmati. Alam tidak menyediakan makanan siap saji untuk dinikmati manusia. Manusia masih perlu mengolah sendiri makanannya. Semuanya masih perlu digarap manusia dengan kerja dan kreatifitas yang maksimal.

\section{Kerja Bukan Akibat Dosa}

Alkitab, khususnya dalam Perjanjian Lama tidak melihat kerja sebagai akibat dosa. Hal ini dapat dilihat pada saat sebelum jatuh dalam dosa, manusia ditempatkan Allah di Taman Eden untuk mengusahakan dan memelihara taman itu (Kej. 2:15). Itulah pekerjaan pertama manusia sebelum jatuh dalam dosa, dimana manusia memaknai kerja

${ }^{9}$ Robert J. Banks, God the Worker: Journeys into the Mind, Heart, and Imagination of God (Sutherland: Albatross Books, 1992) 103. 
sebagai usaha untuk memanusiawikan dunia agar menjadi tempat huni yang nyaman.

Tidak bisa dipungkiri pula, bahwa ada perspektif lain yang menganggap kerja mencari nafkah adalah hukuman Tuhan akibat dosa, dan hal ini biasanya merujuk pada saat manusia dihukum Tuhan untuk bersusah payah mencari rezekinya dari tanah (Kej. 3:17-19). Tentu saja pandangan ini akan berdampak pula pada sebuah anggapan bahwa jika seandainya manusia tidak jatuh dalam dosa, manusia mungkin bisa hidup santai tanpa bekerja. Namun, Alkitab perlu dipahami secara teks dan konteks, seperti yang telah disebutkan di awal, yakni manusia sudah bekerja sebelum kejatuhannya dalam dosa. Bedanya, kerja sesudah kejatuhan dilakukan dengan bersusah payah dan berpeluh.

Meski dikenal sebagai kitab yang bernuansa muram dengan banyaknya ungkapan kesia-siaan, ternyata kitab Pengkotbah juga tidak memandang kerja secara negatif. Kitab ini merumuskan bahwa tidak ada yang lebih baik daripada bergembira dan menikmati hidup, makan, dan minum serta menikmati hasil jerih payah bekerja sebagai pemberian Allah. ${ }^{10} \mathrm{Hal}$ ini tersurat berulangkali dalam ungkapan "tidak ada yang lebih baik bagi manusia daripada

\footnotetext{
${ }^{10}$ Roland E. Murphy, Wisdom Literatur: Job, Proverbs, Ruth, Ecclesiastes, and Esther (Grand Rapids: Eermans Publishing, 1981) 131.
}

bergembira dalam pekerjaannya, sebab itulah bahagianya" (Pkh. 3:22) atau "tak ada yang lebih baik bagi manusia daripada .... bersenang-senang dalam jerih payahnya .... inipun dari tangan Allah" (Pkh. 2:24; 5:17; $8: 15)$.

\section{Kerja Sebagai Ibadah}

Dalam bahasa Ibrani, kata untuk kerja dan ibadah dapat merujuk pada sebuah kata yang sama, yakni Hd"Pb.[' ('aboda). Kesamaan itu masih terlihat dari kata Indonesia "ibadah" yang diserap dari bahasa Arab yang serumpun dengan bahasa Ibrani. Di lingkungan keagamaan, kata $\mathrm{Hd} " \mathrm{~Pb}$.[' ('aboda) dipakai untuk Perayaan Paskah (Kel. 12:25-27; 2 Taw. 35:10), Hari Raya Roti Tak Beragi (Kel. 13:5), juga pekerjaan di Kemah Pertemuan (BiI. 4:33-35), dan ibadah di Rumah TUHAN (1 Taw. 23:2832).

Kata Hd"Pb.[' ('aboda) juga dipakai untuk kegiatan bekerja di luar lingkungan keagamaan, baik itu misalnya mengerjakan tanah liat (Kel. 1:14), mengerjakan ladang (1 Taw. 27:26), bekerja untuk upah (Kej. 29:27; 30:26), melakukan pekerjaan sehari-hari (Mzm. 104:23), menjadi prajurit (Yeh. 29:18), dan bahkan menjadi budak (Im. 25:39). Dari kata Hd"Pb.[' ('aboda) yang 
dapat digunakan untuk konteks ibadah dalam lingkungan keagaamaan dan konteks kerja di luar lingkungan keagamaan, maka dapat dimengerti bahwa bekerja adalah sesuatu yang baik dan dapat dihayati sebagai sebuah pemenuhan kehedak Tuhan.

Konsep Hd"Pb.[' ('aboda) dapat berimplikasi kepada setiap pekerjaan yang baik merupakan perluasan dari pekerjaan Allah. Pekerjaan yang baik adalah pekerjaan yang memberi kontribusi positif pada apa yang dikehendaki Allah agar dilaksanakan di dalam dunia. Allah telah memberi teladan dan amanat kepada umat-Nya untuk menjadi saksi kebenaran Injil. Oleh sebab itu, kehidupan umat-Nya harus menyatakan komitmen terhadap kasih kepada Allah dan kasih kepada sesama. Salah satu cara utama untuk menunjukkan kasih kepada Allah adalah dengan menjadi mitra-Nya untuk bekerja bersama bekerja mengolah dan memelihara bumi ini.

\section{Kerja Sebagai Pengembangan Relasi}

Bekerja akan menciptakan terjadinya beragam bentuk relasi antar manusia: relasi dengan pemerintah (pembayaran pajak), dengan karyawan, dengan pimpinan, dengan pelanggan, dengan penyuplai, dengan kompetitor, dan dengan alam. Namun relasi dasar setiap pekerjaan terangkum dalam dua bentuk, yakni antara pemberi kerja (tuan atau majikan) dan pelaksana kerja (hamba dan pekerja). Mungkin alasannya mengapa Paulus harus secara khusus menulis surat kepada Filemon dan mendorong Onesimus, si budak untuk kembali kepada tuannya. Bukan maksud Paulus ingin menentang sistem perbudakan atau menyetujui sistem perbudakan. Relasi majikan-pekerja tidak ditentang Paulus, karena menentangnya berarti menolak konsep kerja.

Paulus hanya ingin meletakkan relasi majikan-pekerja dalam suasana baru karena relasi tersebut berada dalam Tuhan. Dengan mendorong Onesimus kembali kepada Filemon dan mendorong Filemon untuk menerima Onesimus, Paulus ingin mewujudkan suatu transformasi sosial dengan menunjukkan kepada dunia bahwa relasi tuan-hamba dalam persekutuan Kristes berbeda dengan yang terjadi di masyarakat. Baik majikan ataupun budak, mereka samasama adalah milik Kristus dan bekerja untuk memuliakan Kristus.

\section{Konsep Ad Majorem Dei Gloriam Sebagai Pemenuhan Sacred Calling Ad Majorem Dei Gloriam adalah} sebuah istilah Latin yang dipopulerkan pada abad ke-16 oleh Ignatius Loyola, seorang teolog dan imam dari ordo Jesuit. Secara literal Ad Majorem Dei Gloriam dapat diterjemahkan sebagai "demi kemuliaan 
Allah yang lebih besar,"11 dan secara konseptual istilah ini dapat dipahami bahwa setiap tindakan dan aktivitas manusia di bumi, baik itu belajar, berkomunikasi, bekerja, beribadah, dan lainnya harus dipersembahkan demi kemuliaan Allah.

Gerard Hopkins yang mengutip dari Ignatius Loyola memaparkan bahwa segala sesuatu yang ada pada alam ini adalah anugerah termanis dari Allah. Alam, makanan, benda, orang, peristiwa, segala sesuatu dalam hidup ini diberikan oleh Allah, dan kemuliaan Allah termanifestasikan dalam setiap kebaikan-Nya yang ada di dunia ini. $^{12}$ Allah memanggil manusia untuk memuliakan Allah dalam segala yang mereka bisa kerjakan, tidak hanya dalam aktivitasaktivitas hidup rohani, tetapi dalam dunia dimana mereka dipanggil. Oleh sebab itu, dalam kaitannya dengan kerja, maka manusia bisa menerapkan konsep Ad Majorem Dei Gloriam, yaitu saat manusia memiliki pengakuan akan panggilan Allah dalam bidang pekerjaannya masing-masing dan mempersembahkan jerih lelahnya untuk kemuliaan Allah.

Sebagaimana dalam perspektif Alkitab mengenai kerja, maka dapat dimengerti bahwa pada dasarnya bekerja

\footnotetext{
${ }^{11}$ Joseph A. Munitiz, Personal Writings: Saint Ignatius of Loyola (New York: Penguin Books, 1996) 115.

${ }^{12}$ Gerard Hopkins, The Gospel in Gerard Manley Hopkins: Selections from His Poems, Letters,
}

merupakan panggilan Allah yang kudus (sacred calling) kepada umat-Nya, sebagaimana Allah adalah Sang Pekerja Agung, maka Allah ingin manusia menghadirkan konsep kerja sebagai bentuk ibadah kepada-Nya. Mandat bekerja harus dilakukan dengan memiliki relasi dan tanggung jawab kepada Tuhan. Relasi dan tanggung jawab tersebut tumbuh dan dikembangkan lewat hati nurani.

Hati nurani ini sebagai wakil Allah di dalam diri manusia yang berfungsi untuk merekam segala keputusan, tindakan, dan perilaku yang dilakukan manusia ketika ia menjalankan mandat bekerja. Rekaman tesebut akan menuntut tanggung jawab seseorang terhadap tindakan dan perilakunya selama ia bekerja dimanapun ia dipanggil, baik itu dalam aktivitas rohani maupun dalam aktivitas sekuler. ${ }^{13}$ Dengan demikian orang yang bekerja akan melakukan pekerjaannya bukan hanya demi kepentingan atasan atau institusi dimana ia bekerja, namun ia melakukan pekerjaannya dalam tanggung jawab kepada Allah, yang dapat melihat sampai ke dalam hati nuraninya.

Dalam konsep Ad Majorem Dei Gloriam harusnya tidak ada dualisme antara secular work (bekerja di bidang sekuler) dan

Journals (London: Association of Catholic Publishers, 2016) 98 .

${ }^{13}$ Eduard Lohse, Theological Ethics of The New Testament (Minneapolis: Fortress Press, 1991) 91 
contemplative work (bekerja di bidang rohani), khususnya jika berkompetisi mengenai manakah yang paling berkenan di hadapan Allah. Keduanya sama-sama adalah sacred calling, karena yang membedakan adalah bukan tempat dimana manusia bekerja, melainkan adalah tujuan manusia berkerja. Jika tujuannya diarahkan untuk kemuliaan Allah, maka ini sudah sejalan dengan mandat bekerja yang Allah berikan kepada manusia.

Luther pun menolak pandangan dualisme antara secular work (bekerja di bidang sekuler) dan contemplative work (bekerja di bidang rohani). Ia menolak pandangan bahwa kehidupan di monasteri (menjadi biarawan, imam, pendeta) lebih superior dibandingkan dengan kehidupan di ranah umum. Untuk menyenangkan Allah tidak harus menjadi pertapa di monasteri, tetapi bisa dengan cara menjalankan hidup di dunia keseharian. ${ }^{14}$ Bahkan orang-orang di Abad Pertengahan dianggap oleh Luther telah menyempitkan pemahaman bahwa pekerjaan yang baik hanya yang berhubungan dengan doa, pelayanan, gereja, dan persembahan untuk gereja. Padahal menurut Luther, kuncinya bukan terletak pada aktivitas yang mereka lalukan, tetapi

\footnotetext{
${ }^{14}$ Amos Sukamto, "Teologi Kristen Tentang Kerja (Vocation) Pada Masa Pra-Reformasi dan Reformasi, “ Jurnal Transformasi 9, no. 1 (Juni, 2013), 82-83
}

pada keyakinan mereka untuk memuliakan Allah dalam apapun pekerjaan mereka. ${ }^{15}$

Seperti halnya Luther, John Calvin bahkan mengkritik konsep dualisme dunia kerja antara yang sekuler dengan yang rohani. Dipengaruhi doktrin predestinasinya, Calvin sangat meyakini bahwa pekerjaan sehari-hari (apapun itu) adalah God's calling, karena setiap manusia sangat dimungkinkan untuk menemukan pekerjaan apa yang Allah inginkan dalam hidup seseorang. Semua pekerjaan adalah baik selama ada dalam panggilan Allah dan dilakukan dengan tanggung jawab kepada Allah. ${ }^{16}$ Ada satu kenyataan yang menyolok di gereja sejak paruh abad ke-20, yaitu meluasnya gagasan panggilan. Jika dulu panggilan selalu berkonotasi religius, namun kini orang boleh menhayati panggilan Allah dalam bidang apa saja pekerjaan mereka, seperti menjad ibu rumah tangga, guru, petani, pedagang, dokter, dan lainya.

Ide mengenai panggilan yang meluas itu jauh sebelumnya telah disinyalir oleh Calvin dalam Institutes X.6. Calvin melihat kelemahan manusia yang karena ambisinya sering tak tahu diri dan bertindak di luar batas kemampuannya, sehingga menimbulkan kekacauan. Oleh sebab itu, Calvin

\footnotetext{
${ }^{15}$ Martin Luther, A Treatise on Good Works (Rockville: Serenity Publishers, 2009) 25

${ }^{16} \mathrm{R}$. Paul Stevens, God's Business: Memaknai Bisnis Secara Kristiani (Jakarta: BPK Gunung Mulia, 2008) 57.
} 
berkeyakinan bahwa Tuhan dalam hikmat dan kasih-Nya tak mau melihat manusia hidup sembarangan tanpa arah. Untuk itu, sacred calling dalam bekerja menjadi perlu, dimana orang boleh saja menjalani pekerjaan yang berbeda-beda, asalkan itu sesuai dengan penugasan dari Allah atas dirinya. Dalam konteks ini maka di mata Allah, tidak ada pekerjaan yang hina dan kotor, pekerjaan yang indah, atau pekerjaan yang tak indah; selama seseorang menghayati panggilan Allah dalam pekerjaannya dan memuliakan Allah dalam pekerjaannya.

Max Weber, seorang sosiolog Jerman memaparkan bahwa sumbangsih Luther dan Calvin yang meletakkan konsep panggilan Allah dalam dunia kerja telah memunculkan sentimen positif bagi masyarakat Barat pada waktu itu. Mereka terdorong untuk memproyeksikan perilaku religius mereka ke dalam aktivitas sehari-hari, termasuk dalam dunia kerja. ${ }^{17}$ Dengan kata lain, bagi Weber orang yang mengaku dirinya religius akan terlihat bukan saat dia rajin beribadah dan berdoa saja, namun juga terlihat dalam cara hidup dan etos kerjanya sehari-hari di dunia.

Ada kesaksian klasik dari Nicholas Herman dari Lorraine, seorang bruder awam Perancis (dikenal dengan panggilan bruder Lawrence), yang hidup pada abad ke-17. Tak

\footnotetext{
${ }^{17}$ Max Weber, Etika Protestan dan Spirit Kapitalisme (Yogyakarta: Pustaka Pelajar, 2006) 8.
}

banyak diketahui orang mengenai hidup dan kariernya, selain kerjanya di dapur. Ia dikenang dengan kebiasaannya menghayati hadirat Allah dalam kesehariannya. Meskipun ia bekerja di dapur, kehadiran dan berkat dari Allah dihayatinya sama seperti saat ia berdoa dan beribadah di gereja. Dari dirinya keluarlah doa terkenal yang menjadi kata-kata mutiara untuk hiasan dinding:

"Ya Tuhan atas panci, wajan, dan perabot rumah tangga! Jadikanlah aku seorang kudus saat aku mengambilkan makanan bagi orang lain dan membersihkan piring." 18

Bagi Bruder Lawrence, kerja sederhana dan rutin dalam keseharian disertai tanggung jawab dan takut akan Allah menjadi jalan penghayatan dan pengamalan iman dalam rangka pemenuhan sacred calling.

\section{KESIMPULAN}

Dalam perspektif tujuan ilahi, Allah menginginkan manusia bekerja sama dengan manusia lain dan dengan Allah untuk dapat memenuhi tujuan-Nya. Salah satu tujuan utama Allah di bumi adalah mendatangkan Kerajaan-Nya yang dapat dilakukan melalui pekerjaan manusia di berbagai sektor kehidupan secara profesional dan penuh takut akan Allah. Saat bekerja, nama baik Kristus dipertaruhkan. Permasalahannya

\footnotetext{
${ }^{18}$ Brother Lawrence, The Practice of the Presence of God (Old Tappen: Fleming Revell, 1977) 29.
} 
bukan apakah sebuah pekerjaan termasuk sekuler atau rohani, melainkan seberapa jauh nilai-nilai kristiani dibawa dalam bidang kerja. Penciptaan dua kutub antara dunia rohani dan sekuler tak sesuai dengan gagasan Alkitab dan pemikiran para Reformator (Luther dan Calvin). Perbedaan antara bidang kerja rohani dan sekuler harusnya menjadi penyeimbang dan pelengkap satu sama lain, bukan malah mengunggulkan satu di atas yang lain. Yang terpenting adalah bekerja dengan sacred calling dengan sebuah tanggung jawab dan kesadaran Ad Majorem Dei Gloriam.

\section{DAFTAR PUSTAKA}

Augustine, St. The City of God. New York: The Modern Library, 1950.

Banks, Robert J. God the Worker: Journeys into the Mind, Heart, and Imagination of God.

Sutherland: Albatross Books, 1992.

Hardy, Lee. The Fabric of this World: Inquiries Into Calling, Career Choice, and the Design

of Human Work. Grand Rapids: Eerdmans Publishing, 1990.

Hatta, Mohammad. Alam Pikiran Yunani. Jakarta: Universitas Indonesia, 2006.

Hopkins, Gerard. The Gospel in Gerard Manley Hopkins: Selections from His Poems,

Letters, Journals. London: Association of Catholic Publishers, 2016.

Lawrence, Brother. The Practice of the Presence of God. Old Tappen: Fleming Revell, 1977.

Lohse, Eduard. Theological Ethics of The New Testament. Minneapolis: Fortress Press, 1991.
Loomis, Louise Ropes. On Man In The Universe. New York: Walter J. Black, 1943

Munitiz, Joseph A. Personal Writings: Saint Ignatius of Loyola. New York: Penguin Books,

1996.

Luther, Martin. A Treatise on Good Works. Rockville: Serenity Publishers, 2009.

Murphy, Roland E. Wisdom Literatur: Job, Proverbs, Ruth, Ecclesiastes, and Esther. Grand

Rapids: Eermans Publishing, 1981.

Sinamo, Jansen dan Eben Ezer Siadari. Teologi kerja Modern dan Etos Kerja Kristiani.

Jakarta: Institut Dharma Mahardika, 2011.

Steer, Simon M. Why Work? Careers and Employment in Biblical Perspective. Grand

Rapids: Baker Book House, 1986.

Stevens, R. Paul. God's Business: Memaknai Bisnis Secara Kristiani. Jakarta: BPK Gunung

Mulia, 2008.

Stott, John. Isu Isu Global Menentang Kepemimpinan Kristiani. Jakarta: Yayasan

Komunikasi Bina Kasih OFM, 2005.

Sukamto, Amos. "Teologi Kristen Tentang Kerja (Vocation) Pada Masa PraReformasi dan

Reformasi,“ Jurnal Transformasi 9, no. 1 (Juni, 2013)

Weber, Max. Etika Protestan dan Spirit Kapitalisme. Yogyakarta: Pustaka Pelajar, 2006. 